\title{
Parenting Experience in the Indigenous Balinese Village, Indonesia
}

\author{
Nice Maylani Asril ${ }^{1}$ \\ Department of Health Development, Graduate School of \\ Biomedical and Health Science Hiroshima University \\ Japan \\ 1d1655177@hiroshima-u.ac.jp
}

\author{
Luh Ayu Tirtayani ${ }^{2}$ \\ Department of Early Childhood Education \\ Universitas Pendidikan Ganesha,Singaraja \\ Bali, Indonesia \\ 2ayutirtayani@gmail.com
}

\begin{abstract}
The customary village of Tenganan Pegringsingan is one of the oldest villages in Bali that still practices the ancient tradition in everyday life. The familial system that adopts the bilateral system and the peculiarities of the village of Tenganan Pegringsingan bring about a unique parenting experience for the parents and the child. This study was aimed at exploring parenting experience in the bilateral system viewed from the social-emotional aspect in children of the customary village of Tenganan Pegringsingan. The study employed indigenous psychology with indigenization from within. It used in-depth interview and observation as the methods of data collection. The results showed that children in Tenganan Pegringsingan culture consist of two stages of development called cerik and rare. Each has a unique developmental phase and influences the parenting practice experience. The value to maintain the purity of lineage kindles the spirit of everyday parenting experience. These nurture values are the basis of the community's success in maintaining its existence as an old village (Bali Aga) in the midst of today's modern society.
\end{abstract}

Keywords: indigenization, child's socio-emotional development, parenting experience, Bali Aga

\section{INTRODUCTION}

Involvement on the tradition in community village is a key step to build the good social connection for every community members [1]. The community members who actively have a good engagement with others, perceive their neighborhood to feel safe, the ability of parents to support their children, children's safety and have a positive sense of belonging [2]. This study focused on an observation of parenting experience in early year child's social and emotional development in the community village. The observation was made since the child's social and emotional development will influence the child's later development. Foot, Woolfson, Terras, and Norfolk state that social, emotional and behavioral problems will hinder the child from a full participation in the preschool curriculum and opportunity to get an education, and from optimization of his or her ability [3]. Emotion can be defined as external physical activities, both in the form of pleasant and non-pleasant reaction to a certain event or mental condition. The pleasant reaction is related to a positive emotion whereas the non- pleasant one to a negative emotion [4].

Emotion is a form of communication for the child to state his or her need and feeling to other people. Emotion plays a role in influencing personality and the child's adaptation to his or her social environment [5]. The family is the first and the most important environment for the early year child's emotional development. It is in the family the child has his or her first experience. Family plays the most important role in internalizing the basics of emotional experience. Even in more specific terms, a family can become emotional security in the first stage of the child's development. Family can also take the child to a larger environment. The first social experience outside the home completes the experience at home and is the most important determinant of the social attitude and pattern of the child's behavior.

The writers described the social and emotional development of the early year children at the customary village of Tenganan Pegringsingan to explore parenting experience with a bilateral system. The family system of the village of Tenganan Pegringsingan is bilateral and is obviously different from that in other Balinese villages [6]. The consequence of the bilateral system is that a male child and a female child have the same statuses o rights. All of the children are heirs to the properties of their parents' (both their fathers and mothers) irrespective of the gender of the children or the order of their births. This system will influence the difference in the parenting practice by their parents compared to that in other villages in Bali [7]. The parenting practice in the customary village of Tenganan Pegringsingan plays the role as the supporter of the existence of the culture and tradition in the community of Tenganan Pegringsingan [7].

This study was conducted at the customary village of Tenganan Pegringsingan, situated in the district of Manggis in the regency of Karangasem, Bali. The customary village of Tenganan Pegringsingan (henceforth called Tenganan) is one of the oldest villages in Bali. Geographically, the position of Tenganan is in a canyon between some hills that surround the village. At a close observation, the series of hills in Tenganan starts from Bukit Kangin continues to Bukit Kaja and Bukit Kauh that form the natural walls that split the 
village from other villages. Generally, Tenganan is an area that consists of hilly land, dry land, and wetland. The topographically, Tenganan stretches from north to south, with the total area of 917.2 Hectares. Most of Tenganan villagers are peasants $(59.4 \%)$, sellers $(11.8 \%)$, artisans $(15.9 \%)$, civil servants $(6.1 \%)$, private business workers $(4.8 \%)$, and others (2\%). The population is 577 . On the basis of the distribution of the villagers, most of them have got some education from kindergarten to tertiary education.

Historically, some villages that are regarded as the old villages in Bali are Sembiran, Sidatapa, Sukawana in Singaraja in the north part of Bali and the famous Trunyan in Bangli, and Tenganan Pegringsingan and the customary village of Dauh Tukad in Karangasem. They are closely related historically, religiously and traditionally [8], [9]. As an old village, Tenganan is a village that has developed into a very famous cultural tourism village. The position of Tenganan that is close enough (only about 3 kilometers) from the Candi Dasa beautiful beach makes it one of the tourism objects in Karangasem particularly and in Bali generally. The most important reason why tourists go to this village is to see the "uniqueness" of the culture and customs. As an old village in Bali, Tenganan has unique characteristics. A close observation of this village shows that the village is different from the villages that are generally found in Bali. Not only does it differ in the context of religion (the villagers admit that they are Hindus with the sect Indra (the God of war and rain), it also differs in the ritual practice and everyday life social practices, including particularly in the method of educating and parenting of children. The study focused on the experience of parent and community involvement and the local value of childcare in Tenganan Pegringsingan.

\section{RESEARCH METHOD}

This study used two approaches, which were complementary to each other. The approaches were indigenous psychology and phenomenological interpretive analysis. Through indigenous psychological study, the researchers wanted to understand the parenting experience with a bilateral system from the social and emotional aspects of the development in the children at the customary village of Tenganan Pegringsingan in their cultural context [10]. The indigenous psychological study oriented to the strategy of indigenization from without. In the indigenization from without the researchers built a more systematic knowledge of the parenting experience with a bilateral system from the aspect of the social and emotional development of the children that could be tested theoretically and empirically with the local cultural context of the customary village of Tenganan Pegringsingan.

The phenomenological interpretative analysis was used to help the researchers in exploring the deep meaning of the particular experience of the individuals and people involved in the experience [11]. In the phenomenological analysis, the meaning of the personal life experience was explored from the people that were directly related to the experience [12]. The end result of the two approaches that were employed complementarily was a new knowledge about the parenting experience with bilateral system viewed from the aspect of social and emotional development in the children in the customary village of Tenganan Pegringsingan in their cultural context.

\section{FINDING AND DISCUSSION}

The life cycle concept in Tenganan Village. The people of Tenganan believe that the life of the people of Tenganan consists of a life cycle that rotates like a wheel. Ramseyer describes the pattern of the life cycle of the people of Tenganan as Theater of the Universe taken from the cradle ritual [13]. In the cradle ritual, there are four stopping points, namely bottom (marking the birth state), left (marking the adolescent state), top (marking the adult state) and right (marking the senile state). The cradle rotates to the left (anticlockwise). The rotation to the front marks the maturity, the physical development, and increase in activity. The four points in the cradle at the same time become the marks of the four stages in the development and life of the people of Tenganan. Each stage is also marked by a change, both biologically and socially.

In every process in the cradle rite, the stamping of a male's foot that moves the cradle is the symbol of the process of the passage in each stage. Every stamping of the male's foot represents strength and social capital to enter further stages faced by a Tenganese. In general, such philosophy also signifies that the Tenganese is taught to always understand that human life experiences the ups and downs. The position of a woman in the cradle plays an important role since in addition to having the same position as the man; she also is also regarded as the major source of life as the one who gives births to the next generation.

Every member of the community of Tenganan is officially accepted to have passed a stage and in the process of arriving at the next stage if he or she has done a particular customary rite. The following part describes the four stages of development as the rotation of a cradle in the life of a Tenganese.

\section{Birth}

Birth is the first stage in life. Birth is the beginning stage and is situated at the bottom of the cradle. There is a particular rite that marks this stage, namely the offering to Kanda Empat. Kanda Empat is believed to follow the birth of a child. Kanda Empat consists of blood, amniotic fluid, fetal membrane, and placenta. Spiritually, Kanda Empat is believed to play an important role in the stages of the child's further development. Thus, during a period of some weeks, they are offered food such as bananas, rice, coconut sugar, and beans. The rite for Kanda Empat for the first time is led by Balian luh or Balian muani (female or male traditional medical practitioner). Meanwhile, the offerings on the next days are offered by the family. In the period of about 42 days, 
the mother of the baby experiences sebel/ leteh (the period in which the woman is dirty) as the consequence she is not allowed to participate in a customary activity and to visit a sacred place in the village of Tenganan. In this period, the mother has the obligation to accompany her baby and serves all its needs.

\section{Adolescence}

The adolescent stage is situated at the left of the cradle. The adolescence is marked by the puberty experience. Then the boy is called truna while the girl daha. Truna and daha are the second stages in the development of a Tenganese. In addition to the maturity of the function of the genital (puberty), the status as truna and daha is obtained through a series of social readiness and customary rites. The attempt at making the child ready as truna and daha are likened to entering "Tenganan Academy". This process is important since a truna or a daha has had an obligation in a series of rites.

\section{Adulthood}

The stage after adolescence is the stage of becoming an adult. In the cradle, this stage is represented by the top of the cradle, $180 \%$ from the birth stage. If the birth stage is the beginning period, the adult period is the top of all activities. The adult stage in the community of Tenganan is marked by marriage. The couples who have been solemnized in a marriage directly become customary members of Tenganan. Thus, the process of marriage marks the adult stage and at the same times the door to the customary member status. The adult stage is also called an active stage for the Tenganese since in this stage the customary activity is participated actively by the married couple.

\section{Senile Stage}

The senile stage is represented by the right side of the cradle of life. In this period, the married couples do not have the status anymore as the active members in the Tenganan custom. The active member status can terminate if the children of the couple have married. Thus, the child couples replace the status of their parents. The old couples (the parents) who are no longer active in the custom are called krama gumi pulangan. In this stage, a member of Tenganan community focuses more attention to household activities, taking care of their grandchildren, participating in their pastime activities, or helping with the cultivation of land.

Based on the concept of a cradle of life, the $90^{\circ}$ range that starts from the point of birth and ends at the adolescence is called the childhood or "nak alit". The childhood is not defined as a rigid stage, as other stages that are represented as four stopping points in the cradle of life. This is due to the fact that the communities of Tenganan believe that childhood is a process. Calling some people children represents a process that is given to the people that are in the stage of development. Childhood in the context of Tenganan culture is a period that continues from birth to puberty. In terms of an age range, childhood in Tenganan is in the range of ages $0-11 / 12$. In the context of Tenganan culture, puberty becomes a marker of the end of childhood. The rule in Tenganan custom stipulates that when a person has undergone puberty, he or she is called truna or daha. Truna is a designation for a young boy and daha for a young girl.

In the Tenganan culture, the period after birth up to puberty or what is called childhood is divided into two. The two divisions are called "cerik" and "rare." A child in Tenganan is called cerik when he or she is in the range of 0 - 1/1.5 years of age. A child in this period is treated exclusively that he or she has got no chance to go out from the house and socialize in the environment outside the house. It is believed that the child is in a risky situation to experience negative things that are related to the mystic. People with bad intention regard a child as a weak person who is unable to refuse mystical treatments. When a child is ill, the family and the neighbors automatically think that the illness is caused by a mystical treatment of bad people. The family will immediately call a village traditional medical practitioner to cure the illness besides taking the child to the village community health center. The period of cerik category ends with the performing of magetep jambot rite. Magetep jambot is a ritual of cutting hair for the first time and is performed when a child is minimally one year old. If a child is one year old, and at that time is a dewasa ayu (a good day) to perform a rite, then the rite of magetep jambot can be performed. However, if a dewasa ayu has not come yet, the performance of the rite will be postponed up to the time when a dewasa ayu comes. The rite is a symbol of the end of the cerik period for a child in Tenganan, at the same time, as the door to enter the next stage of development, namely rare period.

Rare is the child development at the age of 1.5 to the time of puberty (11-12 years old). This stage of development gives the child a task to start to open relations with people outside the core family. The parents believe that the child has reached a safe phase to go outside of the house to interact with other people in the environment, but the parents still accompany and watch the child. The child is provided with "bekel" (talisman) to protect him or her from negative things. The child who has been at this age is sent to a preschool. The parents will join the interactions with the child in the classroom during the playtime. When the child enters elementary school, the parents give the chance to the child to go to school alone. The priority is given to the child to remain in the village environment during the play activities and once in a while he or she is brought to the place outside the village to play under the parent's full supervision. The school age children also get the chance to interact with the young people in the customary village (truna and daha). The school age children are involved in a series of activities to prepare them to become truna and daha to enter "The Academy of Tenganan." This involvement is aimed at the first orientation of the children to the customary obligations later when they become adolescents.

Children have some unique position in Tenganan 
communities. Children play a role and have a value as the agent to preserve culture and tradition in the customary village of Tenganan. The value to be maintained and the purity of lineage inspire the daily experience in parenting. The parents actively meet the needs and want of the child. The parents try their best to help the child from the time child eats to the time the child takes a bath. The parents tend to tolerate the child's misbehaviors with the hope that the child will have no intention to leave the village later. The tendency to practice a permissive parenting is aimed at making the child stay in a comfort zone and wants to stay in the customary village family environment.

On the other hand, authoritarian parenting is also practiced by the parents in Tenganan and is aimed at making the child obedient to the rule of the customary village. The parents directly give advice to the child in order that when the child has become an adult, he or she will actively do his or her customary obligations. The child's freedom is restricted so that he or she cannot interact or play outside of the customary village environment to reduce the effect of socializing outside the customary village. The recess and the play time are respectively done simultaneously by the Tenganan people. At noon the child has to take a rest at home and when the sun has gone down, he or she is given a chance to play around the house. At the time of social preparation for "Academy of Tenganan", the children will be picked by the prospective truna and daha to participate in the activities. In the activities, the children will be groomed beautifully by the prospective truna and daha to please them and make them want to be involved in the activities.

Women and men are equal in the customary village of Tenganan Pegringsingan. This is due to the fact that the customary community adheres to a bilateral family system. Sons and daughters have the same status. This is apparent in the presence of sangkepan desa luh (women's meeting) and sekeha daha (women's organization). Other women in Bali, in general, do not have these since according to the Balinese customary law, a heir is a son, a step son and a daughter who has changed her status into a son because of the parents do not have a son as long as she does not lose her right as the heir.

The existence of the equal position between women and men makes the absence of different dimensions of parenting role applied by both of them in their family. This study is supported by Fagan, et.al. which states that the role of parenting applied by both mother and father can be studied using the same dimensions [14]. Based on these statement, it can be understood that the parenting practices are equal for sons and daughters.

In Tenganan Pegringsingan, mother dominates the parenting of a daughter. Mother is not only regarded as mother in the family but also as a senior who will teach skill and bequeath the customary obligations to the daughter. The same is true with father. Father besides being a father, also functions the teacher and caregiver of the son. Based on
Lamb, et.al., mothers and father behave differently in interaction with their children [15]. Mother with maternalchild interaction dominated by caretaking. In other side, father-child interaction characterized by play and other physical activities. Although there is a clear division in relation to the teaching of skill and customary obligations between a father and a mother, it does not mean each of them forget their tasks to educate children who have a different gender from them. Interpersonal communication that occurs in the core family has an important role in keeping the relations between the father and the mother. The interpersonal communication in the core family also has the role as the means to introduce and teach customary obligations that will be done by the children later. Of course, all of these are done to maintain the culture and tradition of Tenganan Pegringsingan in their community.

The parenting practice obviously gives an impact to the child's social and emotional development in the customary village of Tenganan Pegringsingan. The child's ability to explore the new environment seems low. This is shown by the tendency of the children to be less expressive and open when interacting with a person who they have just known. The children also seem to be less initiative and show a fright behavior and a hesitation when interacting with a person who they have just known. The children seem to be very dependent on their parents so that are less independent in taking care of their bodies.

The condition of the children can be understood as the impact of parenting. It should be recalled that parenting behavior is a transfer from parenting experiences received by parents, which are then re-applied to their children [16]. Thus, in nurturing the reflected social values are adopted by the parents of the environment. It also includes the concept of the world as well as habits in behaving in the face of a problem.

In retrospect, the village of Tenganan Pegringsingan geographically describes the existence of 'natural fortress', which seems to block public access to the village. Spatially, the location of Tenganan Pegringsingan Village implies the provision of boundaries between villagers and others. Peoples with these characteristics tend to reinforce social values of self-limitation in interactions with others. Children will tend to be educated to accept and survive. Other local values that characterize the child's development in care are the emphasis on the concept of 'purity of blood and offspring'. Parenting to maintain blood purity is created and reinforced in daily practice in society. One of them looks at parents' efforts in making decisions for their children. In the social development of emotions, children will tend to be very submissive, less initiative, feel less capable in competition, and more dependent on their parents

\section{CONCLUSION AND SUGGESTIONS}

There is a crisis in each stage of life for every member of 
the customary village of Tenganan Pegringsingan. The strength and social capital are needed by every individual to enter the next stages. The Tenganan people are taught to always understand that human life undergoes ups and downs. Childhood in Tenganan Pegringsingan culture consists of two stages of development which are called cerik and rare. Each has a unique developmental phase and influences the parenting practice experience. The value to maintain the purity of lineage status which kindles everyday parenting experience. However, there are disadvantages of the parenting model in which the impact on the high dependence of the child on the parent and the sense of inadequacy in competing. As a follow-up, we can examine the optimization of other resources in care to reduce these negative impacts on children.

\section{REFERENCES}

[1] G. Winkwoth, M. McArthur, M. Layton, and L. Thompson, "Someone to Check in on Me: Social capital, Social support and Vulnerable Parents with Very Young Children in the Australian Capital Territory," Child Fam. Soc. Work, vol. 15, no. 2, pp. 206-215, 2010.

[2] J. Lush and B. Boddy, "Reflections on the Value of a Supportive 'Village' culture for Parents, Carers, and Families: Findings from a Community Survey," J. Soc. Incl., vol. 5, no. 2, pp. 44-55, 2014.

[3] H. Foot, L. Woolfson, M. Terras, and C. Norfolk, "Handling Hard-toManage Behaviours in Pre-School Provision: A Systems Approach," J. Early Child. Res., vol. 2, no. 2, pp. 15-138, 2004.

[4] M. Lewis and J. Haviland-Jones, Handbook of Emotion, 2nd ed. New York: Guilford, 2000.

[5] J. W. Santrock, Life Span Development. New York: McGraw-Hill, 2000.

[6] I. G. A. A. P. INDRAYANI, "Perkawinan Menurut Desa Adat Tenganan Pegringsingan Kabupaten Karangasem Bali," Universitas Gadjah Mada, Yogyakarta, 2007.

[7] N. M. Y. Sudaryati, "Communication Pattern in Balinese Family ( A Study of Nuclear Family's Communication Pattern in Communicating Bali Aga's Custom in Tenganan Pegringsingan, Karangasem, Bali), Indonesia. J. Commun. Stud., vol. 1, no. 2, pp. 200-212, 2008.

[8] T. A. Reuter, The House of Our Ancestors: Precedence and Dualism in Highland Balinese Society. Leiden (Netherlands).: KITLV Press., 2002.

[9] B. Hauser-Schäublin, “'Bali Aga' and Islam: Ethnicity, Ritual Practice, and 'Old-Balinese' As An Anthropological Construct," Indonesia, vol. 77, no. April, pp. 27-55, 2004.

[10] U. Kim, K. S. Yang, and K. K. Hwang, "Contributions to indigenous and cultural psychology: Understanding people in context," in Indigenous and cultural psychology: Understanding people in context, U. Kim, K. S. Yang, and K. K. Hwang, Eds. New York: Springer, 2006, pp. 3-25.

[11] E. Lyons and A. Coyle, Analysing Qualitative Data in Psychology. Los Angeles, New Delhi and Singapore: Sage Publications, 2007.

[12] J. A. Smith, P. Flower, and M. Larkin, Interpretative Phenomenological Analysis: Theory, Method and Research. London: Sage, 2009.

[13] U. Ramseyer, The Theatre of the Universe: Ritual and Art in Tenganan Pegeringsingan, Bali. Basel: Museum der Kulturen Basel, 2009.

[14] J. Fagan, R. Day, M. E. Lamb, and N. J. Cabrera, "Should Researchers Conceptualize Differently the Dimentions of Parenting for Father and Mothers?," J. Fam. Theory Rev., vol. 6, no. 4, pp. 390-405, 2014.

[15] M. E. Lamb, J. H. Pleck, E. L. Charnov, and J. A. Levine, "Paternal
Behavior in Humans," Am. Zool., vol. 25, no. 3, pp. 883-894, 1985.

[16] R. A. Dore, E. R. Stone, and C. M. Buchanan, "A Social Values Analysis of Parental Decision Making," J. Psychol. Interdiscip. Appl., vol. 148, no. 4, pp. 477-504, 2014. 